\title{
Obituaries
}

Obituaries should be submitted by email to Kate Maynard at k.maynard@nature.com.

All submitted obituaries should be 350 words maximum in length (apart from obituaries fo past presidents of the BDA

where the length should be $700-800$ words)

Content of the obituary is down to the individual author, and the approval of the family should be given for the obituary prior

to submission to the $B D J$.

\section{JACK HALESTRAP}

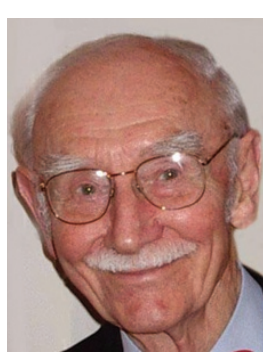

Jack died on 30 March after a fall in the town of Tiverton where he had lived and worked since 1953; he was 92-years-old and had lived a full life.

Jack was born in

North London in March 1917. The eldest of three children, he moved to Kingswood in Surrey when he was 6-years-old; he was educated at Whitgift School in Croydon and worked first for the Guardian Insurance Company and then joined the Royal Bank of Scotland in the City. Being in the Territorial Army, Jack was called up on the first day of war and spent six-and-a-half years in the Army.

In 1947, being married to Margery and having two children, Jack decided on a complete career change and started studying dentistry at Guy's Hospital; he qualified in 1952 and worked in a practice in Sutton before relocating to Tiverton in Devon to work in the School's Service.

In 1954, Jack started two practices; the smaller one he sold soon afterwards and he built up the Park Road practice where he continued working until his retirement in 1984.

Jack was actively involved in the local BDA section and was its President for a year. He was a founder member of the Exeter and District Orthodontic Study Circle, as well as serving on the Local Dental Committee and Exeter Family Practitioner Committee until the age of 70 .

Jack and Margery had many happy years of retirement, with more time to enjoy their grandchildren and spend time working in their garden which gave them so much pleasure. Central to Jack's life was his Christian faith and he was heavily involved with St. George's Church in Tiverton where he was church warden for many years; he was instrumental in the building of the church extension in the late sixties and was a keen supporter of Christian Mission both at home and overseas. Jack was also keen on working for greater Christian unity locally. In his retirement, he was chairman of the Tiverton Volunteer Centre.

Jack leaves his wife Margery, his three children - David who followed his father into dentistry, Frances and Andrew - six grandchildren and two great grandchildren. A service of Thanksgiving was held on 14 April in St. George's Church and we remembered a kind, generous and wise person - a credit to his family, his profession and his faith in Jesus.

David Lyddon

\section{GRAHAM SMART}

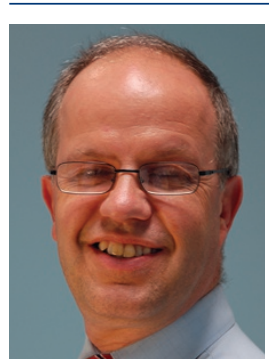

Graham Smart died on 20 June 2009, at the tragically early age of 55. His stoicism in the face of his deteriorating health was truly remarkable. His last professional engagement was a joint lecture that he gave to 900 people in Solihull, just three weeks before his death, a commitment that he was determined to fulfil, against all the odds. This was typical of his dedication to his profession.

Graham qualified from UCH in 1975 and after house jobs and spells in community, NHS and private practice he joined the RAF in 1980. His clinical skills and sharp intellect were quickly identified and his 16-year military career included specialist training in periodontics and posts as Clinical Adviser in Periodontics, Director of the RAF School of Dental Hygiene, RAF Postgraduate Tutor and Adviser in General Dental Practice. His outstanding contribution to the RAF Dental Branch was recognised with the Lean Memorial Award in 1994. On leaving the RAF in 1996 Graham concentrated on specialist periodontal practice but, having a gift and passion for teaching, he dedicated much of his time to postgraduate education for both dentists and hygienists, as well as working in the Oxford postgraduate deanery. He was always active in the British Society of Periodontology and had the honour of serving as President of the Society in 2007/8.

Graham tackled everything with passion, whether it was dentistry, teaching, rugby or the church. He was one of the most warm-hearted, generous and enthusiastic practitioners in his field and his skills as a communicator and teacher were reflected in the enormous number of messages of condolence that were received when news of his death became known. The word 'inspiration' was used repeatedly, as was the description of 'gentleman'. He was a true gentleman and indeed a gentle man. His legacy will be the dentists and hygienists up and down the country who benefited from his inspirational teaching, as well as the patients whose dental care improved as a result. Everyone who encountered him will remember him with enormous affection.

Graham is survived by Mary, his wife of 33 years, and their children Dan, Nick, Rachel and Hannah and granddaughter Talitha.

Phil Ower 